\title{
Disappearance: How Shifting Gendered Boundaries Motivated the Removal of Eighteenth Century Boxing Champion Elizabeth Wilkinson from Historical Memory
}

Christopher Thrasher, New Mexico Military Institute

\begin{abstract}
In the eighteenth century, one fighter's reputation outshone all others. She was Elizabeth Wilkinson, a bare-knuckled, trash talking, knife wielding, European boxing champion. Both throughout her life and a century and a half thereafter, writers heaped praise at her feet. She provided a point of imperial pride for authors that pointed to her as proof that the British of both genders were strong and brave. This began to change at the end of the nineteenth century. As the British Empire seemed in danger of collapse and the American economy shifted unpredictably, men on both sides of the Atlantic basin began to redefine their masculinity. They embraced a new form of passionate manhood that judged men as lovers, athletes, and for their ability to give and withstand pain in the boxing ring. Boxing, which had long been British regardless of gender, now became male, regardless of nationality. Men built a mythical past for boxing that ignored Wilkinson and crowned one of her contemporaries, James Figg, the sport's first champion.
\end{abstract}

\section{Introduction}

In her 1987 book On Boxing, Joyce Carol Oates argues that "boxing is a purely masculine activity and [that] it inhabits a purely masculine world." ${ }^{\prime 1}$ While this was certainly a reasonable observation in 1987, boxing was not always men's exclusive domain. In his classic 1829 work of boxing history Boxiana, the English author Pierce Egan described the dividing line in boxing as nationalistic rather than gendered. He argued that boxing belongs to the British, British women as well as British men. ${ }^{2}$ To establish this, he cited Elizabeth Wilkinson, an eighteenth century European boxing champion (alternatively referred to

\footnotetext{
${ }^{1}$ Joyce Carol Oates, On Boxing (Garden City: Dolphin/Doubleday, 1987), 72.

${ }^{2}$ Pierce Egan, Boxiana Or, Sketches of Ancient and Modern Pugilism (London: Sherwood, Jones, and Co, 1823), 300.
} 
in other sources as Elizabeth Stokes indicating that she might have married the pugilist and fight promoter James Stokes). ${ }^{3}$ Egan quoted her proclamation in the June 1722 edition of the Post wherein she stated, "I, Elizabeth Wilkinson, of Clerkenwell, having had some words with Hannah Hyfield, and requiring satisfaction, do invite her to meet me on the stage and box with me." Egan was not alone. 150 years after her career ended, writers praised Wilkinson more than any of her contemporaries. ${ }^{5}$ This only changed as part of broader societal shifts at the end of the nineteenth century.

Today, few boxing fans know Wilkinson's story. James Figg, one of her contemporaries, overshadows her in modern accounts. Recent histories of boxing such as the official record book for the International Boxing Hall of Fame refer to Figg as "the father of boxing" but make no mention of Wilkinson. ${ }^{6}$ Another work provides an even more blunt appraisal, arguing that "the modern history of boxing begins with James Figg" while once again making no reference to Wilkinson. ${ }^{7}$ This paper argues that society purposely ignored Wilkinson's story when her narrative no longer supported newly dominant notions of gender hierarchy. This paper supports this thesis with three crucial claims; that Wilkinson's career closely paralleled and even overshadowed Figg's, that Wilkinson received greater attention than Figg from authors for roughly one hundred and fifty years after her career ended, and finally that Wilkinson was only forgotten when her story contradicted the new gendered vision of society. We forgot Wilkinson not because of her failures, but because of ours. We sacrificed truthful recollection on the altar of cultural expediency.

\footnotetext{
${ }^{3}$ Lucy Inglis, "Elizabeth Stokes, Lady Bare - Knuckles," http://www.georgianlondon.com/elizabeth-stokes-lady-bare-knuckles ${ }^{4}$ Egan, Boxiana, 300; For examples of sources referring to Elizabeth Wilkinson as Elizabeth Stokes see: John Manning and Arthur H. MacOwen. The Modern Advertisement; Its Resources and Curiosities. Together with Suggestions for Ascertaining the Value of Newspapers for Advertising Purposes (Philadelphia: J. Manning, 1889) 24; Delilah Montoya, María Teresa Márquez, and C. Ondine Chavoya. Women Boxers: The New Warriors (Houston, Tex: Arte Público Press, 2006) 9.

${ }^{5}$ See for example: Egan, Boxiana in which he praises Wilkinson (p. 300) and barely mentions Figg (p. 21).

${ }^{6}$ James B. Roberts, and Alexander G. Skutt. The Boxing Register: International Boxing Hall of Fame Official Record Book (Ithaca, N.Y.: McBooks Press, 1997), 28.

${ }^{7}$ Jack Anderson, The Legality of Boxing: A Punch Drunk Love? (Abingdon: Birkbeck Law Press, 2007) 12.
} 


\section{Elizabeth Wilkinson}

Surviving documents provide few details about Wilkinson's life. The exact details of her childhood and family remain a mystery, but she appears to have come from a working class English household, which was the background common of eighteenth century English boxers. ${ }^{8}$ She was born in London and proclaimed herself as being "of the famous city of London." ${ }^{9}$ Her birth name, however, remains a mystery. The 1735 work, Lives of the Most Remarkable Criminals, describes the life and crimes of Robert Wilkinson, a notorious prize fighter, thief, and murder, executed for his crimes on 24 September $1722 .{ }^{10}$ The work's section on Wilkinson ends with a reprint of the newspaper advertisement, printed just days after Wilkinson's execution, in which Elizabeth Wilkinson makes her first appearance in the documentary record. ${ }^{11}$ The document, in which Elizabeth Wilkinson challenged Hannah Hyfield to meet her in the ring, appears without commentary, leaving the reader to assume a connection between the executed criminal and the woman who shared his last name. ${ }^{12}$ Christopher James Shelton speculated that Wilkinson was not her legal name, but that she adopted it as a stage name, calculated to strike fear into the hearts of would be opponents by suggesting a connection to the infamous Robert Wilkinson. ${ }^{13}$ After her first documented fight in 1722 , her career lasted until roughly $1728 .{ }^{14}$ There is far more convincing evidence connecting Elizabeth Wilkinson to the boxing promoter and pugilist James Stokes, than to the executed criminal

\footnotetext{
${ }^{8}$ Richard D. Mandell, Sport, a Cultural History (New York: Columbia University Press, 1984) 148.

${ }^{9}$ Egan, Boxiana, 300, “Advertisement" Weekly Journal, or The British Gazetteer, October 1, 1726.

${ }^{10}$ The Lives of the Most Remarkable Criminals, Who Have Been Condemn'd and Executed ; for Murder, Highway, House-Breakers, Street-Robberies, Coining, or Other Offences; from the Year 1720, to the Present Time: (London: Printed and sold by John Osborn, at the Golden-Ball in Pater-Noster-Row, 1735) 20.

${ }^{11}$ Ibid., 21.

${ }^{12}$ Ibid., 21.

${ }^{13}$ Christopher James Shelton, “1720's English MMA Fighter: Elizabeth Wilkinson Stokes," http://www.cyberboxingzone.com/blog/?p=7612.

${ }^{14}$ Egan, Boxiana, 300, "Elizabeth Stokes, Pugilist," Daily Post, 1728, Reprinted in New York Times November 12, 1899.
} 
Robert Wilkinson. ${ }^{15}$ Elizabeth Wilkinson probably married her promoter and fellow pugilist, James Stokes. ${ }^{16}$ Such a marriage would explain why she is sometimes referred to as Elizabeth Stokes. ${ }^{17}$ Her probable husband and promoter, James Stokes, was one of Figg's associates, and the two men met in the prize ring on at least one occasion. ${ }^{18}$ After her last documented fight in 1728, she disappeared from the historical record as mysteriously as she entered it. There is no information on why she retired, what she did after leaving the ring, or when she died. ${ }^{19}$ Wilkinson's life, as recorded in the surviving documents, was a brief, glorious, series of moments in the ring that came from nowhere and then quickly returned to the unknown.

\section{James Figg}

The details of James Figg's life, like Wilkinson's, are unclear. Historian Richard D. Mandell argued "we know nothing of Figg's origins" suggesting "he merely appeared." ${ }^{20}$ However, Figg, like Wilkinson, probably came from the English working class; a near universal background for eighteenth century fighters. ${ }^{21} \mathrm{He}$ was probably illiterate. ${ }^{22}$ Figg lived his entire life within a few miles of Wilkinson. He was born in Thame roughly fifty miles from London. ${ }^{23}$ As a young man he moved to London where he turned a vacant lot on Oxford Road into a boxing academy where he lived for the remainder of his life. ${ }^{24}$ Figg's career roughly overlapped Wilkinson's, beginning in 1719 and lasting until his retirement in 1730. He died in 1734; four years after his last

\footnotetext{
${ }^{15}$ Lucy Inglis, "Elizabeth Stokes, Lady Bare - Knuckles,"

http://www.georgianlondon.com/elizabeth-stokes-lady-bare-knuckles

${ }^{16}$ Ibid.

${ }^{17}$ Ibid.

${ }^{18}$ Bob Mee, Bare Fists: The History of Bare-Knuckle Prize-Fighting (Woodstock, N.Y.: Overlook Press, 2001) 8.

${ }_{19}$ Andrew King and John Plunkett. Popular Print Media, 1820-1900 (London:

Routledge, 2004) 279.

${ }^{20}$ Mandell, Sport, a Cultural History, 148.

${ }^{21}$ Mari Womack, Sport As Symbol: Images of the Athlete in Art, Literature and Song (Jefferson, N.C.: McFarland \& Co, 2003) 115.

${ }^{22}$ William J. Baker, Sports in the Western World (Totowa, N.J.: Rowman and Littlefield, 1982) 91.

${ }^{23}$ Eric Dunning and Dominic Malcolm. Approaches to the Study of Sport (London: Routledge, 2003) 281.

${ }^{24}$ Anderson, The Legality of Boxing, 13.
} 
fight and six years after Wilkinson's last recorded fight. ${ }^{25}$ There is no indication that there were any differences in the race, religion, or class of Figg and Wilkinson. The careers of the two fighters shared at least as many similarities as their lives.

\section{Figg and Wilkinson}

Figg and Wilkinson conducted their careers as pugilists of the bare knuckle era in similar ways. Both fighters engaged in varieties of combat. Although typically remembered as a pugilist, Figg was a better fencer and cudgeller than boxer. ${ }^{26}$ Wilkinson fought with daggers, swords, and quarterstaffs as well as with her fists. ${ }^{27}$ Figg and Wilkinson were entrepreneurs and business owners as well as fighters. In his lifetime, Figg's reputation as a teacher sometimes overshadowed his fighting career. ${ }^{28}$ While Wilkinson never achieved the same status as an instructor, she may have owned a school, in partnership with her husband. ${ }^{29}$ Both Figg and Wilkinson were shameless self-promoters. Figg printed business cards that referred to him as the "master of ye noble science of defense" and that pictured him standing on the stage receiving the adulation of fighters and the cheers of the crowd. ${ }^{30}$ In newspapers he referred to himself as the "Oxonian Professor" of the noble science. ${ }^{31}$ Wilkinson promoted herself in similar ways. She called herself the "Invincible City Championess." 32 Self-promotion involved flagrant displays of 'trash talking.' Figg often crowed that he would fight any man in England. When he publicly accepted a challenge from rival fighter James Collins, Figg ridiculed Collins, referring to his challenge as

\footnotetext{
${ }^{25}$ Ernest Cashmore, Making Sense of Sports (London: Routledge, 1996) 82.

${ }^{26}$ Roberts and. Skutt. The Boxing Register, 28.

${ }^{27}$ Catriona M. Parratt, More Than Mere Amusement: Working-Class Women's Leisure in England, 1750-1914 (Boston, Mass: Northeastern University Press, 2001) 36.

${ }^{28}$ Eric Dunning, Dominic Malcolm, and Ivan Waddington. Sport Histories Figurational Studies in the Development of Modern Sport (London: Routledge, 2004) 19.

${ }^{29}$ Catriona M. Parratt, More Than Mere Amusement: Working-Class Women's Leisure in England, 1750-1914 (Boston, Mass: Northeastern University Press, 2001) 36.

30 "Publick Diversions," Universal Mercury, April 1726.

31 Ibid.

${ }^{32}$ Carlo Rotella, Good with Their Hands: Boxers, Bluesmen, and Other Characters from the Rust Belt. (Berkeley: University of California Press, 2002) 41.
} 
amusing. ${ }^{33}$ Like Figg, Wilkinson denigrated her rivals in the press. In a published acceptance of a challenge from an opponent who worked as a mule driver, Wilkinson told readers that "the blows which I shall present her with will be more difficult for her to digest than any she ever gave her asses." 34

Boxing during the careers of Figg and Wilkinson was very different from the highly refined sport of the twenty first century. Boxing matches in the early eighteenth century included wrestling, gouging, and even stomps with spiked boots. ${ }^{35}$ Techniques such as biting, hair pulling, scratching, and gouging were common. ${ }^{36}$ Fights were always bare knuckle; padded gloves only came into practice at the end of the nineteenth century. ${ }^{37}$ Frequently, the contests continued without pause until one competitor collapsed. ${ }^{38}$ Boxing matches featuring women, who typically fought topless, attracted crowds with a potent combination of sex and violence. ${ }^{39}$ Severe injuries and death were common features of early modern boxing. ${ }^{40}$ Historian Robert Brink Shoemaker speculated that up to one in seven murders that were prosecuted in eighteenth century London stemmed from boxing matches or duels. ${ }^{41}$

In spite of the brutality common to eighteenth century boxing, Wilkinson and Figg shared a place at the more refined edge of their sport. Wilkinson often fought under the "half-crown rule." ${ }^{42}$ This rule required each fighter to grasp a half crown coin in each hand, which prevented the gouging and scratching common in eighteenth century

\footnotetext{
33 "Publick Diversions," Universal Mercury, April 1726.

${ }^{34}$ Andrew King and John Plunkett, Popular Print Media, 1820-1900 (London: Routledge, 2004) 207.

${ }^{35}$ Thomas A. Green and Joseph R. Svinth. Martial Arts of the World: An Encyclopedia of History and Innovation (Santa Barbara, Calif: ABC-CLIO, 2010) 228.

${ }^{36}$ Montoya, Márquez, and Chavoya. Women Boxers, 9.

${ }^{37}$ Ernest Cashmore, Making Sense of Sports (London: Routledge, 1996) 82.

${ }^{38}$ Simon P. R. Jenkins, Sports Science Handbook 1 (A - H. Brentwood, Essex: MultiScience Publ. Co, 2005) 351.

${ }^{39}$ Montoya, Márquez, and Chavoya. Women Boxers, 9.

${ }^{40}$ John Rennie, London History: 100 Faces of the East End (London: Lulu, 2006) 118.

${ }^{41}$ Robert Brink Shoemaker, The London Mob: Violence and Disorder in EighteenthCentury England (London: Hambledon and London, 2004) 179.

${ }^{42}$ William Biggs Boulton, The Amusements of Old London; Being a Survey of the Sports and Pastimes, Tea Gardens and Parks, Playhouses and Other Diversions of the People of London from the 17th to the Beginning of the 19th Century (New York: B. Blom, 1969)

30 .
} 
boxing. ${ }^{43}$ While many women fought topless in order to titillate, Wilkinson and her opponents fought fully clothed, indicating they were serious athletes rather than prostitutes. ${ }^{44}$ She was known in her era for fighting in an "organized fashion." ${ }^{45}$ Figg shared this approach; he promoted boxing as an activity worthy of gentlemen and he presented the art as "noble." ${ }^{46} \mathrm{He}$ attempted to organize boxing, helping the sport take its first tentative steps towards respectability. ${ }^{47}$ Although he did not insist on fighting under any particular reformed rules, like Wilkinson, he may have influenced his pupil Jack Brougton who created the first unified code of modern boxing in $1743 .{ }^{48}$ Consistent with this shared approach, Wilkinson fought at Figg's amphitheater. ${ }^{49}$

Figg and Wilkinson both received adulation during their lives. A challenger referred to Figg's reputation as "so highly extolled" and noted that many fighters believed that Figg "is not to be conquer' $d$ by any of woman born." 50 Figg's obituary referred to him as "the noted Prize Fighter." ${ }^{51}$ Figg received praise in his lifetime, yet the title of champion was conspicuously absent. One writer noted that while modern scholars frequently refer to Figg as the English boxing champion, the title would come as a surprise to Figg who was never called the boxing champion while he was alive. ${ }^{52}$ Figg's reputation as a boxing champion is a postmortem accolade.

Wilkinson received even higher praise than Figg during her life. A 1725 report referred to Wilkinson as the "much admired consort" of

\footnotetext{
${ }^{43}$ Laurence Hutton, Other Times and Other Seasons. ( New York: Harper and Bros, 1895.)

${ }^{44}$ James Peller Malcolm, Anecdotes of the Manners and Customs of London During the Eighteenth Century (London: Longman, Hurst, Rees, and Orme, 1810) 155.

${ }^{45}$ Christopher James Shelton, "First Female Fighter, Circa 1720," Ringside Boxing Show, http://ringsideboxingshow.podbean.com/category/elizabeth-wilkinson-stokes/

${ }^{46}$ Roberts and Skutt. The Boxing Register, 12.

${ }^{47}$ Mari Womack, Sport As Symbol: Images of the Athlete in Art, Literature and Song (Jefferson, N.C.: McFarland \& Co, 2003) 114.

${ }^{48}$ Baker, Sports in the Western World, 92.

49 Boulton, The Amusements of Old London, 31.

50 "Publick Diversions," Universal Mercury, April 1726.

51 "Deaths in December," Gentleman's Magazine, December 1734, 703.

${ }^{52}$ Christopher James Shelton, "1720's English MMA Fighter: Elizabeth Wilkinson Stokes," http://www.cyberboxingzone.com/blog/?p=7612.
} 
James Stokes. ${ }^{53}$ When Mary Welch, the champion of Ireland, challenged Wilkinson to a fight, she referred to Wilkinson as the "Championess of England." 54 Before a later fight, a challenger referred to her as the "European Championess." Another source described Wilkinson as "the Cockney Championess." ${ }^{56}$ While the word champion was certainly a compliment, boxing in the eighteenth century, did not have any formal mechanisms for declaring champions. ${ }^{57}$ However, the fact that contemporary observers used the term to describe Wilkinson, but not Figg, provides some insight into their relative stature during the eighteenth century. Consistent with her fame, Wilkinson often headlined the events at which she fought. ${ }^{58}$ Wilkinson's increased prestige and her novelty as a woman in a profession dominated by men made her a favorite for writers in the years after her career ended. ${ }^{59}$

In spite of their efforts, however, boxing only witnessed systematic reforms in the years after Wilkinson and Figg left the arena. ${ }^{60}$ The first serious attempt at reform came in 1743 with the introduction of Broughton's Rules, named for the famed pugilist, which banned attacking a fallen opponent and eye gouging. ${ }^{61}$ The London Prize Ring Rules of 1838 reformed the sport further, prohibiting kicking and holding hard objects in the hands (once a technique Wilkinson used to prevent opponents from gouging or scratching her during fights). ${ }^{62}$ The contemporary rules of boxing with which we are familiar only began to

\footnotetext{
${ }^{53}$ Dianne Dugaw, Warrior Women and Popular Balladry, 1650-1850 (Cambridge [England]: Cambridge University Press, 1989) 125.

${ }^{54}$ Carlo Rotella, Good with Their Hands: Boxers, Bluesmen, and Other Characters from the Rust Belt (Berkeley: University of California Press, 2002) 41.

${ }^{55}$ Henry Sampson, A History of Advertising from the Earliest Times: Illustrated by Anecdotes, Curious Specimens and Biographical Notes (London: Chatto and Windus, 1874) 174.

${ }^{56}$ W. K. Stratton, Boxing Shadows. Austin: University of Texas Press, 2009.

57 Roberts and Skutt. The Boxing Register, 48.

${ }^{58}$ Christopher James Shelton, "First Female Fighter, Circa 1720," Ringside Boxing Show, http://ringsideboxingshow.podbean.com/category/elizabeth-wilkinson-stokes/

59 For example see: Egan, Boxiana, 300; James Peller Malcolm, Anecdotes of the Manners and Customs of London during the Eighteenth Century (London: Longman, Hurst, Rees, and Orme, 1810) 155.

${ }^{60}$ For an excellent history of boxing regulations see Robert George Rodriguez, The Regulation of Boxing A History and Comparative Analysis of Policies Among American States (Jefferson, N.C.: McFarland \& Co, 2009).

${ }^{61}$ Barry Jordan, Medical Aspects of Boxing (Boca Raton, Fla: CRC Press, 1993) 5.

${ }^{62}$ Rodriguez, The Regulation of Boxing, 26.
} 
take shape with the creation of the Queensberry Rules of 1867. Among other changes, the Queensberry Rules required the use of gloves and prohibited wrestling. ${ }^{63}$ Widespread adoption of new regulations often took many years. The first heavyweight championship fight under Queensbury Rules did not take place until John L. Sullivan's 1892 contest with Jim Corbett, twenty-five years after the code's introduction. $^{64}$

\section{Memories of Figg and Wilkinson}

A search of the Google books database for works published from 1700 to 2000 gives some insight into how the English speaking world has remembered these two combatants. For more than a century and a half after both fighters retired, Wilkinson received at least equal, if not more documentary mentions than Figg. This only changes dramatically in the final years of the nineteenth century. Similar data is gleaned from the Proquest database. The graph looks somewhat different, with noted differentiation in more recent dates. References to Wilkinson and Figg only begin to appear in the 1830 s. The shift in numerical dominance from Wilkinson to Figg also appears later, with references to Figg increasing in the final years of the nineteenth century, but only overtaking Wilkinson decades later.

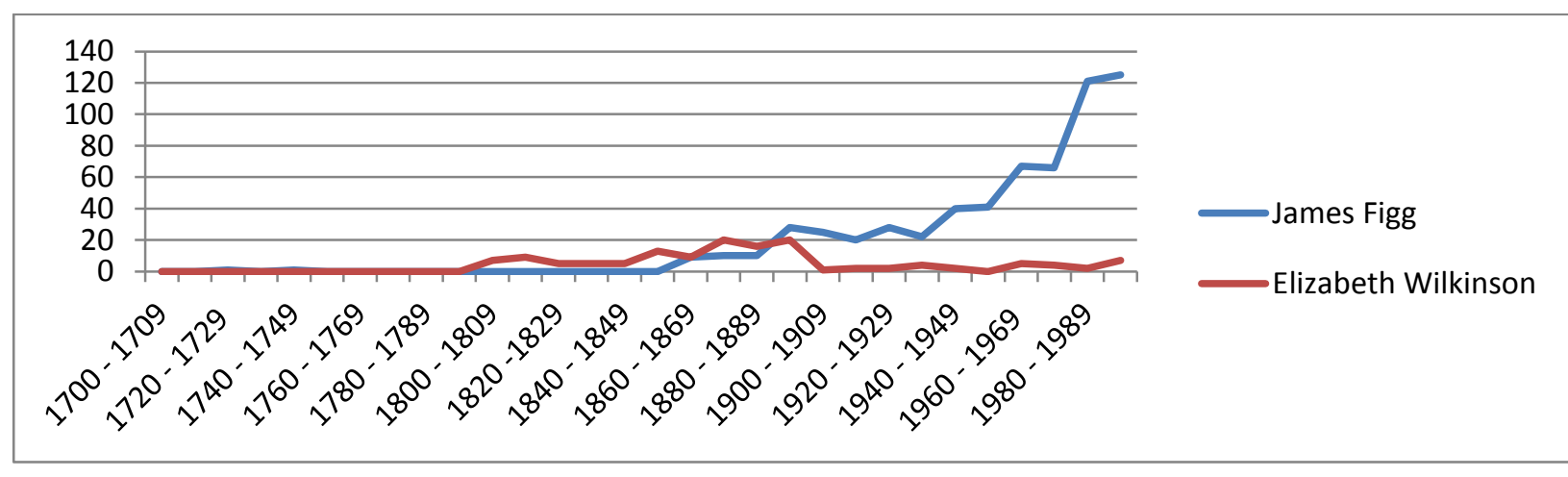

Figure 1 Google Books

${ }^{63}$ Barry Jordan, Medical Aspects of Boxing (Boca Raton, Fla: CRC Press, 1993) 5.

${ }^{64}$ William J. Baker, Sports in the Western World (Totowa, N.J.: Rowman and Littlefield, 1982) 175. 


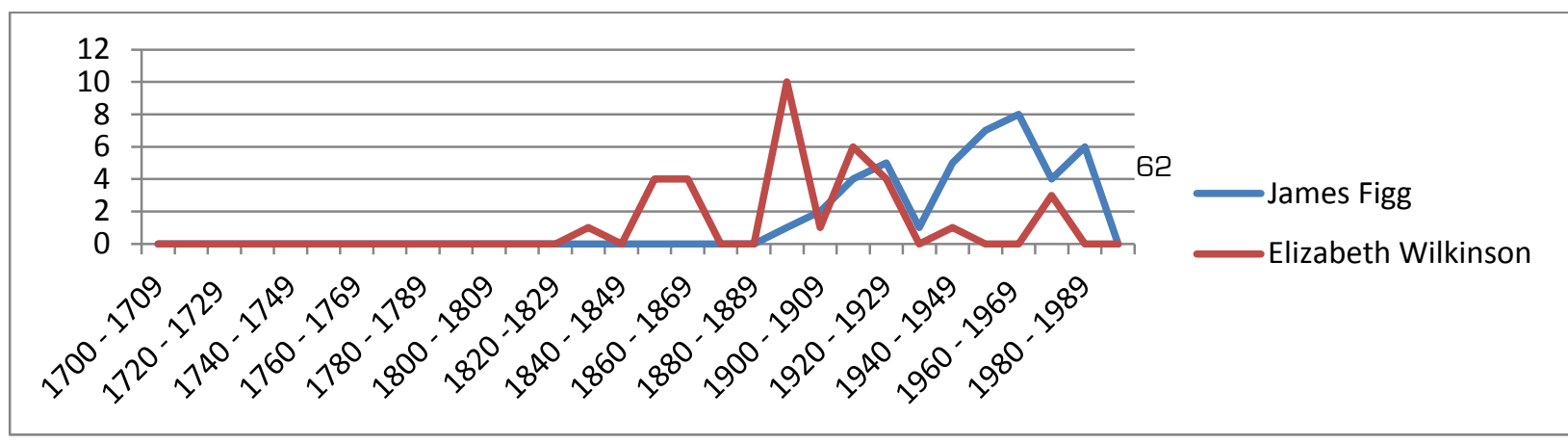

Figure 2 ProQuest

The differences between the two graphs reveal the very different nature of the two databases, but both support this paper's underlying thesis. Google Books consists of roughly fifteen million works, nearly four percent of everything ever published. ${ }^{65}$ The searches for this study were limited to references in English and included works published across the English speaking world, most of which came from England and the United States. Proquest offers a far more limited sample that comes entirely from sources published in the United States and offers a far more limited chronology from 1740 to the present with most of the sources coming from the late nineteenth to the late twentieth century. ${ }^{66} \mathrm{In}$ spite of the differences in the chronological and geographic focuses of these databases, they both reveal very similar patterns. Both graphs support this paper's claim that for over a century and half after the conclusion of Figg's and Wilkinson's careers, the female boxer received far more attention from the sources. While the shift from Wilkinson to Figg did not occur at the same time in these databases, studies of both sources indicate that a dramatic shift did occur and that it occurred

65 John Timmer "Database of Google Books Shows the Half - Life of Celebrity," http://arstechnica.com/science/news/2010/12/googles-digitized-books-provide-verbalculturome.ars

${ }^{66}$ To be more specific, the database includes The American Periodical Series $1740-$ 1900, Historical Annual Reports 1844 - Present, Chicago Tribune 1849 - 1987, Christian Science Monitor 1908 - 1997, Los Angeles Times 1881 - 1987, New York Times 1851 - 2007, Wall Street Journal 1889 - 1993, Washington Post 1877 - 1994. 
sometime between the last years of the ninetieth century and the first years of the twentieth. These graphs beg the question of why?

The answer lies in the constructed meaning of and discourses surrounding boxing. For many years nationality was the crucial dividing line in the world of pugilism. Some English writers claimed boxing as their exclusive national property. ${ }^{67}$ Eighteenth century British pugilists saw themselves as ambassadors of a uniquely British vision of national pride that reveled in its skill with unarmed combat. ${ }^{68}$ Throughout the empire, loyal subjects looked to boxing as "a way of demonstrating British superiority." $" 69$ English writers such as the novelist George Borrow promoted this idea in widely read works of fiction. ${ }^{70}$ A popular nineteenth century song sang in honor of the English champion Tom Cribb expressed English pride in their identity as boxers. In comparison to Italians "who stab their friends behind in darkest shades of night" the song exclaims that "Britons they are bold and kind, and box their friends by light."71 The song mentions gender, but only vis-a-vis national identity, noting that "Since boxing is a manly game, and Britons' recreation; by boxing we will raise our fame, "bove any other nation.,"72 Men accepted women in the ring because they saw them primarily as members of a shared national rather than a separate gendered identity. ${ }^{73}$

Authors used Wilkinson's story as a source of national pride, arguing that her life demonstrated that even English women were courageous and tough. Egan expressed this claim explicitly in his work, reminding his readers of Wilkinson, in order "to show the nationality of boxing and that it is not merely confined to heroes" and celebrating women like Wilkinson who "panted for the honors of pugilistic glory.,"74 Egan was hardly alone in this nationalistic rhetoric. James Peller Malcolm compares French comedians who performed in London to a

\footnotetext{
${ }^{67}$ Egan, Boxiana, 300.

${ }^{68}$ Boddy, Boxing, 37.

${ }^{69}$ Dawne Y. Curry, Eric D. Duke, and Marshanda A. Smith, Extending the Diaspora: New Histories of Black People (Urbana: University of Illinois Press, 2009) 208.

70 Thomas Tracy, Irishness and Womanhood in Nineteenth-Century British Writing (Farnham, England: Ashgate Pub. Co, 2009), 71.

${ }^{71}$ Egan, Boxiana, 495.

${ }^{72}$ Ibid., 300, 496.

${ }^{73}$ Ibid., 300.

${ }^{74}$ Ibid., 300.
} 
fight between the English boxers Wilkinson and Hyfield. Malcolm reports that these women "maintained the battle with great valor for a long time, to the no small satisfaction of the spectators." 75 Thomas Moore was even more direct, arguing that Wilkinson's life was proof that the British were a race of peaceful warriors in the mode of ancient Greece. ${ }^{76}$ Figg, however, received very different converge for most of the eighteenth and nineteenth century.

Authors in the waning years of the nineteenth century neither mention Figg as often nor praise him in equal quantity to that of Wilkinson. The occasional references afford him little special status; he is typically mentioned only in lists of English prizefighters and fencers. Egan praises Figg in noncommittal fashion suggesting merely that Figg "might be looked upon as the champion of that day." ${ }^{77}$ In contrast to later authors such as Roberts and Skutt, Egan appoints Jack Broughton, an English fighter who achieved fame decades after Figg's retirement, as the father of boxing. ${ }^{78}$ George Smith mentions Figg in an article on the artist William Hogarth, a designer of advertisements for Figg's academy. Smith refers to Figg as "a matchless master," but does not suggest he ever held a boxing championship or played a crucial role in the history of boxing. ${ }^{79}$ Edgar James agrees with Smith, referring to Figg as "a man of remarkable athletic strength and agility" but not as a champion and certainly not as the father of anything besides several children. Henry Miles lists Figg in a long line of English boxers, noting that his name occasionally appears among the lists of boxing champions. Miles explains that many fans use the term loosely, referring to every boxer as a champion regardless of their actual accomplishments. He argues that

\footnotetext{
${ }^{75}$ Malcolm, Anecdotes, 154 - 155.

${ }^{76}$ Thomas Moore and J. W. Lake. The Poetical Works of Thomas Moore: Including His Melodies, Ballads, Etc (Paris: A. and W. Galignani, 1827) 187.

${ }^{77}$ Egan, Boxiana, 20, 59.

${ }^{78}$ Roberts, and Skutt. The Boxing Register, 28: Egan, Boxiana,_59. Egan praises Broughton as the writer of the first code of rules widely accepted by English boxers and the unquestioned hold of the English boxing crown for eighteen years 51, 57.

${ }^{79}$ George Smith, "William Hogarth: Painter, Engraver, and Philospher" Cornhill, July to December $1860,105$.
} 
Figg deserves the title of champion only in this very loose sense of the term. ${ }^{80}$ This changed dramatically at the close of the nineteenth century.

The historiography supports this paper's assertion that writers shifted their attention from Wilkinson to Figg during a broader, social redefinition of masculinity. Sally Ledger argues that at the end of the nineteenth century many British men feared that they were becoming effeminate and losing the masculinity that allowed them to maintain the empire. ${ }^{81}$ Mrinalini Sinha agrees, arguing that British masculinity entered a crisis at the end of the nineteenth century as a result of challenges from feminists who demanded increasing political, political, and economic rights. ${ }^{82}$ British women continued their physical ingress by entering traditionally masculine spaces such as gymnasiums and playing fields. In response to female participation in tennis and golf, Patrick F. McDevitt argues that men who were formally divided by boundaries of race and class banded together to make the boxing ring an exclusively male space. ${ }^{83}$ These changes were not limited to the British Isles.

Similar shifts took place in America. Anthony Rotundo argues that beginning in the early nineteenth century; American men celebrated a vision of self-made manhood defined in monetary terms. ${ }^{84}$ As the century ended, men looked at their bodies and worried that business careers were making them effeminate. In the final decades of the nineteenth century, America witnessed a wave of financial disruptions including the panics of 1873 and $1884 .{ }^{85}$ The Panic of 1893 was often called the Great Depression, until it was surpassed by the even worse economic downturn that followed the stock market crash of $1929 .{ }^{86}$ Economic uncertainty further undermined the idea that men could prove

${ }^{80}$ Henry Downes Miles, Tom Sayers, Sometime Champion of England, His Life and Pugilistic Career (London: S.O. Beeton, 1866) 134.

${ }^{81}$ Sally Ledger, "The New Woman and the Crisis of Victoriansim" in Sally Ledger and Scott McCracken, Cultural Politics at the Fin De Siècle ( Cambridge [U.K.]: Cambridge University Press, 1995) 22.

${ }^{82}$ Mrinalini Sinha, Colonial Masculinity: The 'manly Englishman' and The' Effeminate Bengali' in the Late Nineteenth Century (Manchester: Manchester University Press, 1995) 140, 9.

${ }^{83}$ Patrick F. McDevitt, May the Best Man Win: Sport, Masculinity, and Nationalism in Great Britain and the Empire, 1880-1935 (New York: Palgrave Macmillan, 2004) 60.

${ }^{84}$ Rotundo, American Manhood, 19.

${ }^{85}$ Jerry W. Markham, A Financial History of Modern U.S. Corporate Scandals From Enron to Reform (Armonk, N.Y.: M.E. Sharpe, 2006) 607.

${ }^{86}$ Markham, Financial History, 607. 
their worth in the marketplace. As a result, men embraced a new vision of aggressive masculinity, which encouraged men to demonstrate their manhood by building strong bodies and proving themselves as athletes, soldiers, and lovers. ${ }^{87}$ Students and clerks flooded into new athletic clubs, stepped onto baseball diamonds, and learned the art of pugilism. ${ }^{88}$ Other scholars agree with Rotudo's assessment and elaborate on his observations. Elliot Gorn argues that "If the fundamental test of masculinity was, by Victorian lights, being a good breadwinner, if work was a man's primary source of self - definition, the measure of his worth, and proof of his manhood, then many working - class men in industrializing cities were doomed to failure" because in the new economy "daily labor undermined rather than buttressed masculinity. It made sense, then, that many workers turned to a more elemental concept of manhood, one they could demonstrate during the leisure hours." 89 Gorn argues that boxing provided that elemental manhood since "the manly art defined masculinity not by how responsible or upright an individual was but by his sensitivity to insult, his coolness in the face of danger, and his ability to give and take punishment." 90 Preeminent sociologist of masculinity, Michael Kimmel, concurs with Rotundo and Gorn, arguing that the new system of wage labor capitalism that emerged at the close of the nineteenth century undermined traditional masculine values by demanding obedience and docile acquiescence to absolute rules. Work became repetitive, boring, and structured. Some men were unable to find steady work of any kind and faced unemployment. In response, men retaliated, deciding that if they "could not make things with the skill of their hands, they could at least destroy things, or others, with them." womanish" of modern civilization. ${ }^{92}$ Kimmel quotes a boxing fan who took a moment out of his day in 1888 to argue bluntly that "This vaunted

\footnotetext{
${ }^{87}$ Rotundo, American Manhood, 222.

88 Rotundo, American Manhood, 239.

${ }^{89}$ Elliott J. Gorn, The Manly Art: Bare-Knuckle Prize Fighting in America (Ithaca: Cornell University Press, 1986) 141.

${ }^{90}$ Ibid., 141.

${ }^{91}$ Michael S. Kimmel, Manhood in America (New York: Oxford University Press, 2006) 139.

92 Ibid., 138.
} 
age needs a saving touch of honest, old fashioned barbarism, so that when we come to die, we shall die leaving men behind us, and not a race of eminently respectable female saints." 93

As a result of these concerns, men jealously guarded their new found refuge, took measures to ensure that women were excluded, and eyed female influences with suspicion. British educators argued that the poor performance of American high school students was "in large part due to the preponderance of women teachers." 94 President Theodore Roosevelt urged male students to embrace rough sports including boxing as a way to protect themselves from feminizing influences. ${ }^{95}$ Journalists generally approved of female involvement in sports and even encouraged schools to hire them as physical education teachers, as long as women steered clear of the boxing ring. ${ }^{96}$ Advice columnists such as Arthur Dean promoted exercise for men and women, as long as the gendered boundary was maintained, with boxing remaining within the male domain. $^{97}$

Some women resisted male attempts to exclude them from the ring. In 1876, two women fought for a sliver butter dish at a New York theatre. ${ }^{9}$ The National Police Gazette, the most popular journal of American sports during the late nineteenth century, occasionally covered boxing contests between women. ${ }^{99}$ Women competed in demonstration boxing matches during the 1904 St. Louis Olympics. ${ }^{100}$ Several Chicago women took up boxing at a local athletic club in the years before World War I. ${ }^{101}$ Women interested in boxing occasionally found an ally among men. Los Angeles boxing trainer Dewitt Van Court accepted female pupils and reported that his training regimen improved their appearances

\footnotetext{
${ }^{93}$ Ibid., 138.

94 Edward Conradi, "Latin in the High School," The Pedagogical Seminary, March 1905, 9.

95 "Teaching the Boy to Fight," Washington Post, May 31, 1904.

${ }^{96}$ See for example: "New Field for Women," Washington Post, 19 October 1911.

${ }^{97}$ See for example: Arthur Dean "Your Boy and Your Girl," Washington Post, 18 October 1927.

${ }_{98}$ Allen Guttmann, Women's Sports: A History (New York: Columbia University Press, 1991) 101.

${ }^{99}$ Benita Heiskanen, The Urban Geography of Boxing: Race, Class, and Gender in the Ring (New York: Routledge, 2012) 91.

${ }^{100}$ W. K. Stratton, Boxing Shadows (Austin: University of Texas Press, 2009) 79.

101 "War Biff on the Jaw Brightens Eye of the Debutatnt" Mansfield Shield, 20 January 1915.
} 
and limited their tendency toward "hysterics." ${ }^{102}$ At least a few women in Boston boxed during the $1920 \mathrm{~s} .{ }^{103}$ These attempts met with resistance. ${ }^{104}$

Women who expressed interest in boxing during the late nineteenth and early twentieth centuries often met resistance. The British government outlawed women's boxing in $1880 .{ }^{105}$ In the late nineteenth century, women were typically excluded from attending boxing matches in the United States. ${ }^{106}$ School administrator Dr. Beach disbanded the boxing program for female Angelino students, citing public fears that the sport could damage the faces of "pretty girls." ${ }^{107}$ A 1920 article in the Atlanta Constitution presented boxing as entirely inappropriate for women. ${ }^{108}$ Women who joined a Chicago boxing program became the topic of a humorous cartoon in which the opposing fighters were a wealthy woman and her maid, seemingly eager to exact vengeance. ${ }^{109}$

When some women began adding aspects of boxing training into their workouts, the press responded with ridicule. An early twentieth century journalist explained that women were weak, timid, and "afraid of black eyes and stiff jaws, and bruised bodies." ${ }^{110}$ Physicians argued that boxing was far too strenuous for women. ${ }^{11}$ Boxing historian W.K. Stratton concluded that during most the twentieth century, "women's boxing lay dormant." 112

Against this backdrop of laughter and opposition, the cultural memory of Figg and Wilkinson shifted dramatically. The Irish poet and journalist John Boyle O'Reilly may have invented the idea that Figg was the father of boxing; at the very least, he promoted the concept and increased its acceptance. In his 1888 work, Ethics of Boxing and Manly Sport, Reilly attempted to promote "boxing as a healthy and manly

102 "Box," Pittsburg Press, 4 January 1915.

${ }^{103}$ Stratton, Boxing Shadows, 79.

${ }^{104}$ Ibid., 79.

${ }^{105}$ Kath Woodward, Sex Power and the Games (Houndmills, Basingstoke, Hampshire: Palgrave Macmillan, 2012) 40.

106 "Women at the Prize Fight," Sunday Vindicator, 14 March 1897.

107 "Boxing Among Girls Placed Under Ban," Atlanta Constititution, 28 December 1911.

108 "Boxing Not For Women," Atlanta Constitution, 4 April 1920.

109 "War Biff on the Jaw Brightens Eye of the Debutatnt" Mansfield Shield, 20 January 1915.

110 "Boxing Girl Arrives," Washington Post, 30 October 1904.

111 Thomas A. Green, and Joseph R. Svinth. Martial Arts in the Modern World (Westport, Conn: Praeger, 2003) 215.

${ }^{112}$ Stratton, Boxing Shadows, 79. 


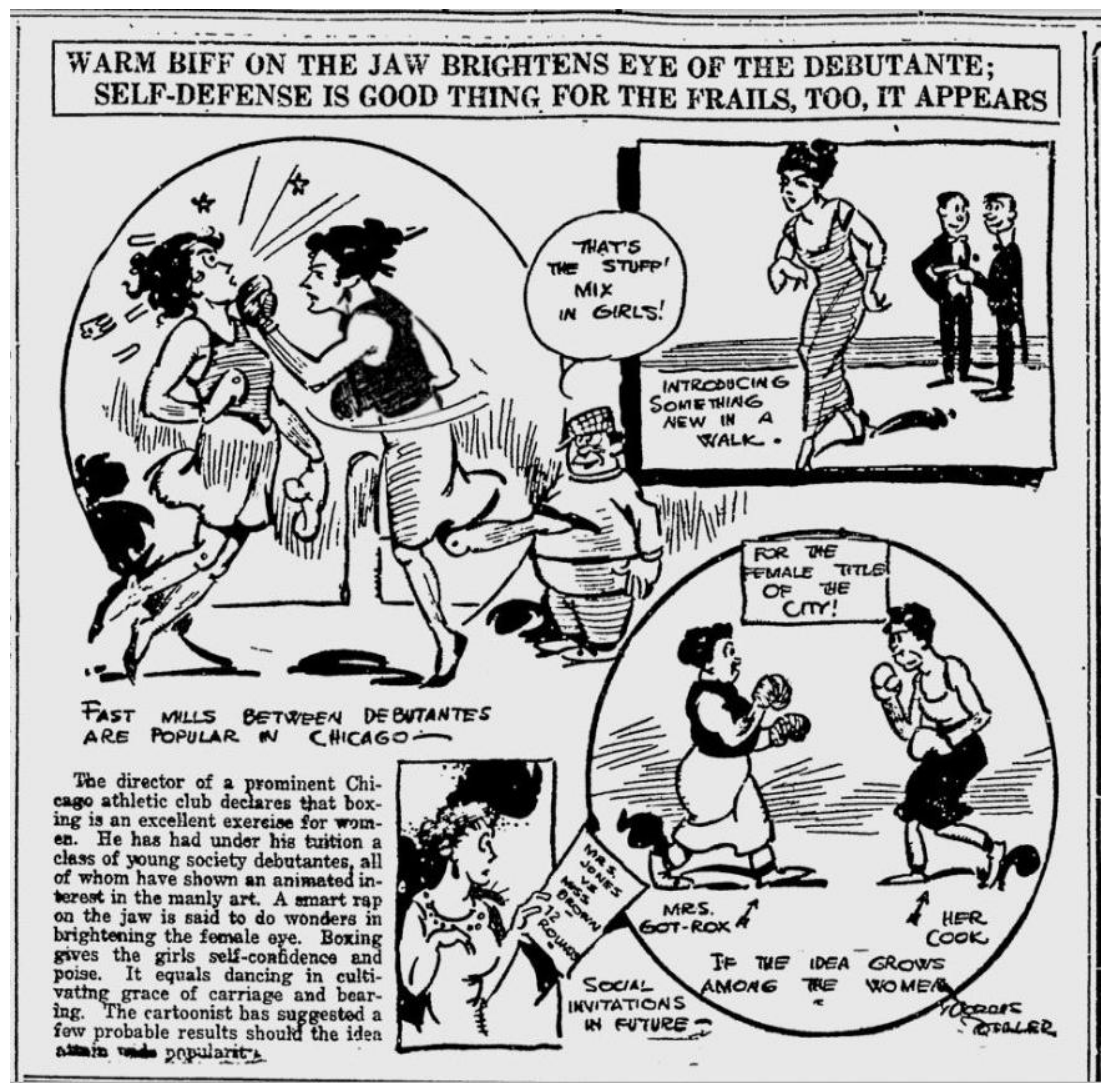

Figure 1.0 - Cartoon from The Mansfield Shield, 20 January 1915.

exercise." 113 He refers to Figg as "the father of boxing" and later calls him "the first English pugilist who can be considered as a national champion." " ${ }^{114}$ Although he praises Figg in unprecedented terms, he notes that Figg was more of a teacher than fighter. Like Egan, O'Reilly reserves his highest praise for Jack Broughton who he terms "the first real fighting champion" a man who was a pure pugilist and not a part timer. ${ }^{115} \mathrm{O}$ 'Reilly repeats these claims almost verbatim in a later work that also promoted sport as a manly activity. ${ }^{116}$ Other authors noticed Figg's increased status and quoted O'Reilly as a source for the

113 John Boyle O'Reilly, Ethics of Boxing and Manly Sport (Boston: Ticknor and Co, 1888) 4.

${ }^{114}$ Ibid., 15, 43.

${ }^{115}$ Ibid., 15, 48.

${ }^{116}$ Ibid., xviii, 15, 43 . 
description of Figg as the father of boxing and a national champion. ${ }^{117}$ While O'Reilly may have paved the way, other authors also worked to transform Figg into an idol of manly virtue.

Writers increasingly remade Figg's image, describing him in terms of masculinity. Barratt O'Hara elevated him from champion to "king of the prize ring" in his 1909 history of boxing. ${ }^{118} \mathrm{He}$ describes Figg as an instructor and practitioner of "the manly art of self-defense" which provides a dramatic shift from the words on Figg's surviving advertisements and all of the previous descriptions of Figg's style as noble, rather than manly. ${ }^{119}$ This shift is consistent with McDevitt's argument that men increasingly worked together across class boundaries to preserve the boxing ring as an exclusively male domain. ${ }^{120}$ The 1914 New International Encyclopedia repeats this new idea, referring to Figg as "the father of the manly art of self-defense." ${ }^{\text {"121 }}$ Robert Edgren, writing for the Chicago Daily Tribune in 1922, gave a brief history of boxing in which he referred to Figg as teaching "ye manly art of self-defense." This is a particularly odd statement since Edgren puts the phrase in quotation marks and borrows the older style English spelling even though every indication suggests that Figg and his contemporaries never described his style in those terms. ${ }^{122}$ Other authors constructed legitimacy for modern pugilists by linking them to this tradition. Mitchell Rawson argued that modern boxers come "straight down from" Figg. ${ }^{123}$ He refers to Figg as a practitioner of "the manly art of self - defense." 124 By 1959, Figg posthumously received the title of "having invented boxing or at least with having fashioned a sport out of what up to then was probably only a manifestation of ale - house individualism." ${ }^{125}$ Figg

${ }^{117}$ See for Example: "Health Matters," Science, January - June 1888, 283.

118 O'Hara, Barratt. From Figg to Johnson; A Complete History of the Heavyweight Championship, Containing Dates and Accurate Descriptions of Every Contest for the World's Boxing Title from the Time of the First Champion Down to the Present Day (Chicago, Ill: The Blossom book bourse, 1909) Front Matter.

${ }^{119}$ Ibid., 7.

${ }^{120}$ Patrick F. McDevitt, May the Best Man Win: Sport, Masculinity, and Nationalism in Great Britain and the Empire, 1880-1935 (New York: Palgrave Macmillan, 2004) 60.

121 “Boxing, "New International Encyclopedia (New York: Dodd, Mead, 1914) 627.

122 Robert Edgren, "Setting the Style in Boxing," Chicago Daily Tribune, 11 June 1922.

${ }^{123}$ Mitchell Rawson, "First World Champion Fought Two Hundred Years Ago," New York Times, 19 September 1926.

124 Ibid.

125 Edwin A. Roberts, “Reading for Pleasure,” Wall Street Journal, 28 April 1959. 
was no longer the icon of manly virtue; he was simply the ancient king of a noble sport. Wilkinson's reputation fell as quickly as Figg's rose.

References to Wilkinson became increasingly rare and generally negative as the nineteenth century progressed. Andrew Wynter argued in 1860 that the modern British Empire was far more civilized than its eighteenth century predecessor and attempted to prove this by listing the nation's history of barbarism. He argued that "worse than this, we encouraged pugilism among the fair sex" and mentions Wilkinson repeatedly. ${ }^{126} \mathrm{He}$ suggests that women were never authentic boxers, explaining how promoters worked to restrain Wilkinson and her opponents from forgetting their training and scratching each other. ${ }^{127}$ In 1880, Gilbert Elliot Minto referred to Wilkinson's fights as examples of boxing matches between women which were "the most revolting and disgusting spectacles"128 By 1882, Wilkinson's tale seems little more than a curiosity. A writer for Chamber's Journal confessed surprise at the discovery that women had once entered the boxing ring and presents the announcement of one of Wilkinson's fights among a list of bizarre advertisements from a distant past. ${ }^{129}$

With the rise of the women's liberation movement after World War II, women obtained greater access to the ring. Many women turned to fighting arts, including boxing, in an effort to protect themselves from assault and to build strong bodies. ${ }^{130}$ Barbara Buttrick, a British born boxer once known as "The Mighty Atom", enjoyed a very successful boxing career during the 1950s. ${ }^{131}$ Since boxing was illegal for women in England, she immigrated to the United States where she won the women's boxing champion following a 1957 victory over Phyllis Kugler

\footnotetext{
${ }^{126}$ Andrew Wynter, "The Curiosities of Civilization," Chamber's Edinburgh Journal, January - June 1861, 28.

${ }^{127}$ Ibid., 28.

${ }^{128}$ Gilbert Elliot Minto, and Emma Eleanor Elizabeth Hislop Elliot-Murray-Kynynmound Minto. Lord Minto in India; Life and Letters of Gilbert Elliot, First Earl of Minto Edited by the Countess of Minto (London: Longmans, 1880) 59.

129 "Some Curious Advertisements," Chamber's Journal, 1882, 400.

${ }^{130}$ Sarah K. Fields, Female Gladiators: Gender, Law, and Contact Sport in America (Urbana: University of Illinois Press, 2005) 125.

${ }^{131}$ Oliver Holt, "Adams and Eve It: History Beckons as Nicola Gets Ready to Land First - Ever Women's Boxing Gold," Mirror, 9 August 2012.
} 
in San Antonio, Texas. ${ }^{132}$ She fought men and women during her career, retiring with a professional record of thirty wins and one loss. ${ }^{133}$ In the 1970s, women obtained boxing licenses in the United States, often after winning lawsuits alleging gender discrimination. ${ }^{134}$ Jackie Tonawanda, often called the Female Muhammad Ali, was probably the most famous of these pioneering women. ${ }^{135}$ In 1975, she defeated Larry Rodania with a second round knockout, earning praise from some reporters. ${ }^{136}$ Women's boxing, however, encountered setbacks as well as victories.

In spite of the gains made by women in boxing, gendered divisions continued to exist. Journalist Valrie Eads noted that some observers suggested either that Tonawanda's victory over Rodania was a fixed fight or that Rodania was a terribly incompetent pugilist. ${ }^{137}$ Former heavyweight champion and chairman of the New York State Athletic Commission Floyd Patterson told a reporter in 1978 that female boxing contests were terrible and expressed his personal revulsion, noting "I can't stand to see women cutting each other up."138 Undefeated professional boxer Michael Dokes argued that boxing is "too physical, too brutal for a woman" since "a woman is supposed to be soft, very gentle, and petite." ${ }^{139}$ In 1982, Jill Lafler, a young woman who hoped to enter the Michigan Golden Gloves tournament, was disappointed when a federal judge ruled in favor of the Golden Gloves organization's ban on female competitors. ${ }^{140}$ British men shared many of these views. Naseem Hamed, a devout Muslim and top ranked British fighter, expressed his opposition to women in any capacity in 1999 claiming that "their breasts and female organs are delicate and vulnerable." Moreover, he made a spiritual argument that "God gave women the wonderful gift of motherhood and all my natural instincts tell me this precious state should

\footnotetext{
${ }^{132}$ David L. Hudson and Mike Fitzgerald. Boxing's Most Wanted: The Top 10 Book of Champs, Chumps, and Punch-Drunk Palookas (Washington, D.C.: Brasseys, 2004) 36.

${ }^{133}$ Heiskanen, Urban Geography, 91.

${ }^{134}$ W. K. Stratton, Boxing Shadows (Austin: University of Texas Press, 2009) 81.

135 "In Ali's Footsteps." Jet, 5 August 1976, 33.

${ }^{136}$ See for example: Valerie Eads, "All Martial Arts Tournament - Second Edition," Black Belt, December 1975, 65; "Woman Boxer Continues," Jet, 10 July 1975, 46.

${ }^{137}$ Eads, "All Martial Arts Tournament," 65.

138 "Male Boxer Don't Want Females in the Boxing Ring" Jet, 9 November 1978, 50.

${ }^{139}$ Ibid., 50.

140 "Boxer Disappointed at Ruling," Times Daily, February 12, 1982.
} 
be protected." ${ }^{141}$ Lennox Lewis, an Anglo-Canadian boxer and holder of the world heavyweight title, described women's boxing as "slapping and hair - pulling in more or less the same league as a circus act or mud wrestling." 142 Bert Sugar, probably the most influential journalist of boxing in the twentieth century recently confessed that "I'd rather poke my eye out with a sharp stick than watch women's boxing." He decried women's boxing as "a circus and a freak show" and as an uncompetitive, freakish, non-sport. ${ }^{143}$ This attitude remains a feature of most boxing histories.

Discussions of boxing continued to evolve. Authors rarely mention either Figg or Wilkinson in the strident gendered language of the past, choosing instead to cite Figg as a historical innovator, while ignoring Wilkinson or only mentioning her as an oddity. The Boxing Hall of Fame's official record book calls Figg the sport's father, but does not even give Wilkinson a footnote. ${ }^{144}$ Nat Fleischer and Sam Andre begin their history of boxing, the product of five years of careful research, with James Figg the "first British heavyweight king" with whom they argue "the art and science of modern boxing begins." 145 These authors do not mention Wilkinson and the only women in their story are wives and girlfriends, not athletes. ${ }^{146}$ Other authors agree and argue that "the modern history of boxing begins with James Figg" while once again failing to mention Wilkinson or the status she long held as England's most noteworthy boxer. ${ }^{147}$ Kasia Boddy does not ascribe to Figg such lofty status, arguing only that Figg was an important teacher of various fighting arts. ${ }^{148}$ Boddy mentions Wilkinson, but only as a curiosity and not as a champion. ${ }^{149}$

141 Jeff Powell, "What Message Do We Send to Boys if Men Punching Women is Sport?” Daily Mail 19 October 1999.

${ }_{142}$ Ibid..

143 Bert Randolph Sugar, Bert Sugar on Boxing: The Best of the Sport's Most Notable Writer (Guilford, Conn: Lyons Press, 2003) 11, 12.

${ }_{144}$ Roberts, and Skutt. The Boxing Register, 28.

${ }^{145}$ Nat Fleischer, Sam Andre, and Don Rafael. An Illustrated History of Boxing (New York: Citadel Press/Kensington Pub, 2001) 7, 8.

${ }^{146}$ Ibid., 86, 183, 441.

${ }^{147}$ Anderson, The Legality of Boxing, 12.

${ }^{148}$ Boddy, Boxing: A Cultural History, 28.

149 Ibid., 28. 
In her award winning book Parlor Politics, Catherine Allgor argued that astute answers to the question 'where are the women?' produce not politically correct history but correct political history."150 Her argument extends beyond the bounds of political history and provides important insights to scholars of every topic. This paper examines the life and legacy of Elizabeth Wilkinson not in a politically correct effort to exaggerate the female contribution to boxing, but rather to better understand how the sport and the memories of it evolved over time. Numerous other scholars have examined how boxing has shifted in terms of class, economics, and art. Yet, no writer has fully explored how those shifts have affected the ways in which boxing is considered and reconsidered by society over time. An understanding of the ebb and flow of Wilkinson's reputation demonstrates the fluidity of perception and helps the reader understand that depictions of the past are often more about today than yesterday.

\section{Contemporary Relevance}

Wilkinson's career is of unprecedented relevance in the first years of the twenty-first century as a new generation of women struggle to make a home in the ring. In 2001, the first sanctioned Women's World Boxing Championship took place. ${ }^{151}$ USA Boxing, the national governing body for Olympic boxing in the United States, counted more than 2,000 women competitors among its members by $2002 .{ }^{152}$ The summer 2012 Olympics featured women's boxing as an official sport for the first time. ${ }^{153}$ Fighters from nations including Tajikistan, Tunisia, Morocco, Korea, and Kazakhstan competed alongside women from Great Britain, Ireland, Australia, and the United States, to name a few.

On 9 August 92012 British fighter Nicola Adams defeated China's Ren

${ }^{150}$ Catherine Allgor, Parlor Politics: In Which the Ladies of Washington Help Build a City and a Government (Charlottesville: University Press of Virginia, 2000) 246.

${ }^{151}$ Montoya, Márquez, and Chavoya. Women Boxers, 11.

${ }^{152}$ Fields, Female Gladiators, 131.

${ }^{153}$ John Home, and Garry Whannel. Understanding the Olympics (Abingdon, Oxon: Routledge, 2012) 170; It is important to note that women demonstrated boxing at the 1904 Olympics, but did not participate as full competitors. See for example: Stratton, Boxing Shadows, 79. 
Cancan to become the first woman in history to win an Olympic gold medal in boxing. ${ }^{154}$ Adams's victory provided retired pugilist Barbara Buttrick, with an opportunity for reflection. ${ }^{155}$ The 82 year old former fighter slowly shuffled her stooped body to her seat for the historic gold medal contest as the fighters entered the ring. ${ }^{156}$ Buttrick explained "When I was around, I would never have dreamed women boxers would ever get into the Olympics." ${ }^{157}$ She predicted that the increased notoriety and credibility that came with Olympic gold will usher women to the sport. ${ }^{158}$ Female boxers continue to face opposition in spite of their success. Cuba, long known for its excellent boxers, decided not to support women's boxing. One of the nation's top coaches, Pedro Roque, explained "women should be showing off their beautiful faces, not getting punched in the face." ${ }^{159}$

In 1987, Joyce Carol Oates argued "boxing is a purely masculine activity and it inhabits a purely masculine world." ${ }^{160}$ Her statement was reasonably accurate for 1987; yet, the life of Elizabeth Wilkinson demonstrates that boxing was not always exclusively a masculine domain. She stood as European champion and provided evidence for observers determined to prove that the British were a tough and courageous people. Lamentably, we refused to write good history when the past clashed with our evolving notions of gender(ed) sensibilities. We sacrificed truthful recollection on the altar of cultural expediency. Today, we can make amends by the restoration of Wilkinson's name to history books and by working to maintain a more truthful recollection of the past.

\footnotetext{
${ }^{154}$ Ben Dirs, "Nicola Adams Wins Historic Boxing Gold for Great Britain," BBC Sports Online, 9 August 2012.

155 Oliver Holt, "Adams and Eve It: History Beckons as Nicola Gets Ready to Land First - Ever Women's Boxing Gold," Mirror, 9 August 2012.

156 Ibid.

${ }^{157}$ Dirs, "Nicola Adams," BBC Sports Online, 9 August 2012.

${ }^{158}$ Ibid.

159 "Olympic Boxing Not for Women: Cuba," CBC News, 21 August 2012.

${ }^{160}$ Oates, On Boxing, 72.
} 